Psihologijske teme, 27 (2018), 2, 311-338

Pregledni rad - UDK - 159.95

159.942

159.937

\title{
Mogu li kognicija i emocije utjecati na vid?
}

\author{
Mateja Marić i Dražen Domijan \\ Sveučilište u Rijeci, Filozofski fakultet u Rijeci, Odsjek za psihologiju, Hrvatska
}

\begin{abstract}
Sažetak
U radu su prikazani teorijski argumenti i empirijske potvrde za ideju i protiv ideje da kognitivni procesi (mišljenje, rezoniranje, očekivanje i vjerovanje) ili emocije i motivacija mogu izravno utjecati na i mijenjati sadržaj vida. Prema hipotezi o modularnosti uma i Marrovoj računalnoj teoriji vid je informacijski zatvoren modul s fiksnom, urođenom arhitekturom. Ona se temelji na specifičnim načelima koja su bitno drugačija od općega kognitivnog funkcioniranja. Vid mora biti kognitivno inpenetrabilan zato jer mora stvoriti točnu mentalnu reprezentaciju vanjskog svijeta i time omogućiti jedinki uspješno snalaženje u njemu. Suprotno tome, prema modelu prediktivnog kodiranja, kao suvremenog oblika zagovaranja penetrabilnosti vida, mozak stalno generira predikcije koje olakšavaju i usmjeravaju procesiranje osjetnih informacija i posljedično mijenjaju ono što vidimo. U novije vrijeme mnoga bihevioralna i neuroznanstvena istraživanja pokazuju da se vid doista mijenja pod utjecajem naučenih asocijacija i konteksta kao i socijalne kognicije, motivacije i emocija, što upućuje na zaključak da je vid kognitivno penetrabilan. Međutim, u navedenim su istraživanjima identificirane brojne metodološke i interpretacijske poteškoće iz kojih proizlazi suprotan zaključak. Na kraju, opisani su mogući smjerovi za daljnja teorijska i empirijska istraživanja koja bi nas trebala približiti razrješenju ovoga složenog pitanja.
\end{abstract} vid

Ključne riječi: eksperimentalna metodologija, emocije, kognicija, kognitivna neuroznanost,

\section{Uvod}

Pretpostavka da je percepcija kognitivno penetrabilna podrazumijeva da različiti kognitivni procesi, poput mišljenja, vjerovanja, emocija, potreba i dr., mogu izravno djelovati na vidno procesiranje tako da mijenjaju njegov konačan rezultat. Dakle, ono što mislimo i osjećamo, doslovno može utjecati na način na koji vidimo

Mateja Marić, Odsjek za psihologiju, Filozofski fakultet Sveučilišta u Rijeci, Sveučilišna avenija 4, 51000 Rijeka, Hrvatska. E-pošta: mmaric2@ffos.hr

Rad je nastao uz potporu projekta Metacognition in Category Learning, Thinking and Comprehension (šifra: 4139), koji financira Hrvatska zaklada za znanost, i projekta Kognitivni i neurodinamički aspekti percepcije, učenja i mišljenja (šifra: 13.04.1.3.11), koji financira Sveučilište u Rijeci. 
svijet oko sebe (Balcetis, 2016; Vetter i Newen, 2014). U terminima obrade informacija u hijerarhijski organiziranom sustavu kao što je vid to znači da silazni ili odozgo-prema-dolje (engl. top-down) procesi mogu izravno utjecati na uzlazne ili odozdo-prema-gore (engl. bottom-up) procese (Palmer, 1999). Međutim, problematična posljedica kognitivne penetrabilnosti jest njezina interferencija $s$ temeljnom zadaćom vida, a to je dostavljanje što točnije informacije o okolini radi lakšeg snalaženja u njoj (Marr, 1982). Iz toga proizlazi da vid nije toliko pouzdan izvor informacija kao što nam sugerira naše svakodnevno iskustvo (Lupyan, 2017b). Stoga je važno teorijsko i empirijsko pitanje postoji li barem dio vida koji je funkcionalno nezavisan od kognicije i emocija. S druge strane, ako su svi aspekti vida kognitivno penetrabilni, pitanje je na koji je način naše ponašanje usklađeno $s$ fizikalnim obilježjima vanjskog svijeta. Ova su pitanja od velike važnosti ne samo za psihologiju nego i za filozofiju uma, neuroznanost, psihijatriju, pa čak i estetiku. Koliko je kognitivna penetrabilnost vida aktualno i važno pitanje, pokazuje i činjenica da su nedavno dva časopisa Consciousness and Cognition ${ }^{1}$ i Frontiers in Psychology ${ }^{2}$ objavili tematske brojeve posvećene upravo ovoj temi. Cilj je ovog rada rasvijetliti prirodu pretpostavke o kognitivnoj penetrabilnosti vida te napraviti pregled teorijskih argumenata za i protiv, kao i empirijskih nalaza koji ih podržavaju. Također, ponudit će se i nove ideje za razrješenje ovoga složenog pitanja.

\section{Neuronske osnove vida}

U okviru neuroznanosti vid je najistraženiji osjetni modalitet. Sva su istraživanja pokazala da vid nije jednostavan proces preslikavanja intenziteta svjetla koje registrira retina u unutarnju reprezentaciju u mozgu, već se sastoji od cijelog niza složenih neuronskih mreža specijaliziranih za analizu različitih aspekata vidnih podražaja (Bulier, 2001; Lennie, 1998). Zbog toga je pri analizi problema kognitivne penetrabilnosti vida potrebno obuhvatiti i neuroznanstvene spoznaje o interakcijama među kortikalnim centrima koji su u njega uključeni.

Obrada vidnih informacija započinje apsorpcijom fotona svjetlosti $u$ fotoreceptorima u retini, a nastavlja se u dva odvojena paralelna puta koji čine parvostanice i magno-stanice. Parvo-stanice osjetljive su na podražaje visoke prostorne frekvencije (jer imaju mala receptivna polja), niske temporalne frekvencije, niskog kontrasta i pokazuju oponentne reakcije na boje (crveno-zeleno i plavo-žuto). S druge strane, magno-stanice imaju velika receptivna polja, osjetljive su na podražaje niske prostorne frekvencije, visoke temporalne frekvencije, visokog kontrasta i ne pokazuju oponentnost na boje (Callaway, 2005). Parvo- i magno-stanice iz lateralne

\footnotetext{
${ }^{1}$ Vol. 47, str. 1-112 (2017), Cognitive penetration and predictive coding. Dostupno na http://www.sciencedirect.com/science/journal/10538100/47/supp/C?sdc=1

${ }^{2}$ Vol. 8 (2017), Pre-cueing effects on perception and cognitive penetrability. Dostupno na http://journal.frontiersin.org/researchtopic/4600/pre-cueing-effects-on-perception-andcognitive-penetrability\#articles
} 
koljenaste jezgre (lat. lateral geniculate nucleus $-L G N$ ) projiciraju u različite slojeve primarnog vidnog korteksa, koji se još označava i kao V1 ili strijatni korteks, ili Brodmanovo područje 17, i predstavljaju prvi korak u kortikalnoj obradi vidnih signala. Projekcije iz primarnoga vidnog korteksa prema ekstrastrijatnim područjima mogu se podijeliti u dva odvojena funkcionalna sustava ili vidna puta. To su ventralni i dorzalni put, koji nastavljaju i dalje elaboriraju subkortikalne parvo- i magnoputove. Ventralni put sudjeluje u identifikaciji objekata, pa se još naziva i što put. S druge strane, dorzalni put ima važnu ulogu u lokalizaciji objekata u prostoru, pa se još naziva i gdje put (Goodale i Milner, 1992; Ungerleider i Mishkin, 1982). Paralelni vidni putovi prikazani su na Slici 1.

Ventralni ili što put

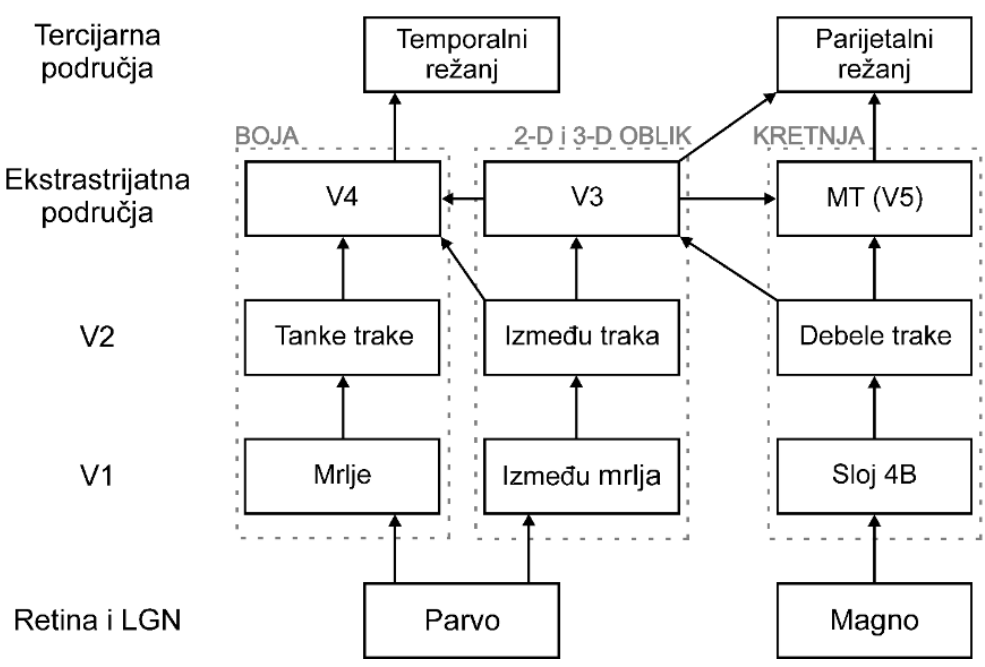

Slika 1. Shematski prikaz paralelnih vidnih putova. Subkortikalni parvo i magno putovi, koji su jasno odvojeni u retini i LGN-u, dalje se u korteksu razdvajaju i elaboriraju. Crni pravokutnici prikazuju anatomske strukture, a sivi iscrtani pravokutnici označavaju funkcionalnu specijalizaciju za boju, oblik i kretnju. Mrlje i trake odnose se na izgled strijatnog korteksa nakon bojenja citokromatskom oksidazom. Prilagođeno prema Coren, Ward i Enns (2003).

Klasičan pristup razumijevanju vida polazi od pretpostavke da opisani vidni putovi čine hijerarhijsku strukturu u kojoj se vid gradi postupno, od elementarnih senzornih obilježja koja se nadograđuju i elaboriraju u nizu kortikalnih centara te na kraju dovode do prepoznavanja objekta u anteriornom temporalnom režnju i prostorne lokalizacije objekta u posteriornom parijetalnom režnju (Lennie, 1998). Iz toga proizlazi da je tok informacija u vidnom sustavu jednosmjeran, odnosno implicira striktno uzlazno procesiranje. Međutim, neuroznanstvena istraživanja pokazuju da među vidnim centrima postoje i brojne povratne veze. One prenose širok raspon informacija, od usmjeravanja pažnje, očekivanja, vrsta perceptivnog zadatka, 
radnog pamćenja pa do motornih naloga kojima dinamički mijenjaju odgovore neurona u vidnim putovima (Gilbert i Li, 2013), što upućuje na direktnu interakciju između uzlaznih i silaznih procesa u vidnom sustavu (Bulier, 2001).

$\mathrm{Na}$ prvi se pogled čini da sam pojam povratnih veza podrazumijeva funkcionalnu povezanost vida i kognicije. Međutim, povratne veze imaju drugačija obilježja od uzlaznih veza. Povratne veze najčešće su modulatorne, što znači da mogu mijenjati aktivnost neurona jedino ako je on već aktivan preko praga, a tu su aktivaciju osigurale uzlazne veze (Sherman i Guillery, 2002). Unutar svakog kortikalnog centra uzlazne i silazne projekcije ostvaruju sinaptičke kontakte u različitom sloju (Callaway, 2004) i ne formiraju snažne povratne petlje (Crick i Koch, 1998). Nadalje, povratne veze ne mogu mijenjati specifično obilježje za koje je neuron osjetljiv, već samo pojačavaju ili smanjuju njegovu reakciju na isto obilježje (Martinez-Conde i sur., 1999). Na osnovu opisanih obilježja Macknik i Martinez-Conde (2009) zaključuju da je glavna uloga povratnih veza održavanje prostorne pažnje na dijelu vidnog polja. Prema Firestoneu i Schollu (2016) za raspravu o interakciji između percepcije i kognicije potrebno je razlikovati mijenjanje procesiranja od mijenjanja ulaza u vid. Na primjer, zatvaranjem očiju ili okretanjem glave možemo kontrolirati ono što doživljavamo vidom, ali tim postupkom mijenjamo samo ulaz u percepciju, a ne i vidno procesiranje, pa se to ne može uzeti kao argument za utjecaj kognicije na percepciju. Slično djeluje i prostorna pažnja jer selektivno usmjerava obradu ka jednom dijelu vidnog polja te na taj način mijenja ulaz u vid. Zbog ovog se razloga ni njezino djelovanje ne može smatrati kognitivnim utjecajem na vid.

\section{Vid kao modul}

Polazeći od Fodorove (1983) hipoteze o modularnosti uma Pylyshyn (1999) razvija i brani ideju o kognitivnoj inpenetrabilnosti percepcije. Prema Fodoru (1983) ljudski se um sastoji od središnjeg sustava, senzornih procesora i ulaznih modula. Središnji sustav čine kognitivni procesi kao što su mišljenje, rezoniranje i donošenje odluka. To je kognitivni aparat kojim se koristimo svjesno i namjerno kako bismo riješili neki problem ili kako bismo razumjeli neku situaciju. Uloga ulaznih modula jest preuzimanje informacija koje registriraju senzorni procesori, odnosno osjetni organi (npr. retina, pužnica, koža i dr.) i preoblikuju ih na način da budu dostupne središnjem sustavu. Temeljna je razlika između središnjeg sustava i modula u tome što su moduli informacijski zatvoreni (inkapsulirani), dok središnji sustav nije. To znači da moduli reagiraju samo na određenu vrstu informacija za koju su specijalizirani, dok središnji sustav može prihvatiti i obraditi bilo kakvu informaciju koja je relevantna za zadatak. Dakle, središnji sustav može primiti informaciju iz svih modula, ali ne može utjecati na module. On nema uvid u to što i kako moduli rade niti može usmjeravati obradu u njima, nego samo dobiva krajnji rezultat njihove obrade. Također, moduli ne mogu stupiti ni u međusobnu interakciju. Štoviše, obrada 
je informacija u modulima automatizirana i oni imaju fiksnu neuralnu arhitekturu, koja je urođena.

Pylyshyn (1999) smatra da je vidna percepcija modul u Fodorovom smislu te riječi. Iz toga proizlazi da svi kognitivni procesi koji su dio središnjeg sustava ne mogu utjecati na vid te je on stoga kognitivno inpenetrabilan. Preciznije, onaj dio vida koji je kognitivno inpenetrabilan naziva se ranim vidom. On obuhvaća procese $\mathrm{u}$ rasponu od registracije svjetla na fotoreceptorima, analize različitih perceptivnih obilježja kao što su boja, oblik, pokret, tekstura, dubina, pa do stvaranja jedinstvene trodimenzionalne reprezentacije površine objekata u okolini (Adelson i Bergen, 1991; Marr, 1982). Rani vid nije pod utjecajem pažnje, pa se još naziva i vid prije pažnje (engl. pre-attentive vision) (Julesz i Bergen, 1983; Treisman i Gelade, 1980). Za razliku od ranog vida, kasni je vid kognitivno penetrabilan, a sastoji se od prepoznavanja i identifikacije objekata na temelju informacija iz dugoročnog i semantičkog pamćenja, usmjeravanja pažnje i svjesnih pretpostavki o percipiranom subjektu. Dakle, semantičke informacije počinju djelovati na vidno procesiranje tek nakon što je rani vid odredio reprezentaciju 3D površine objekata u vidnom polju. Slika 2. shematski prikazuje odnos ranog vida, kasnog vida i kognitivnih procesa. Ovdje treba istaknuti da se pojam vidna percepcija ponekad upotrebljava za skupno označavanje i ranog i kasnog vida, a ponekad samo za označavanje ranog vida. Kako bi izbjegli nejasnoće, u daljnjem tekstu ćemo pojam vidna percepcija koristiti isključivo kao sinonim za rani vid.

Pylyshyn (1999) koncept kognitivne inpenetrabilnosti temelji na Marrovoj (1982) računalnoj teoriji, prema kojoj se vid sastoji od tri odvojene razine obrade koje su posložene u uzlaznu hijerarhiju: prvobitna skica, 2.5D skica i 3D model. Pri tome, rani vid čine prvobitna skica i $2.5 \mathrm{D}$ skica. Najprije prvobitna skica pronalazi promjene $\mathrm{u}$ intenzitetu svjetla na slici, odnosno detektira rubove. Rezultati obrade $\mathrm{u}$ prvobitnoj skici šalju se u 2.5D skicu. Ona potom integrira reprezentaciju rubova s još složenijim aspektima podražaja kao što su stereopsis i pokret. Rezultati analize u 2.5D skici dalje se prenose u 3D model, koji transformira reprezentaciju iz egocentričnoga referentnog okvira u alocentrični, odnosno okvir koji ima ishodište na objektu. Drugim riječima, 3D model osigurava reprezentaciju adekvatnu za prepoznavanje objekata. Iz navedenog opisa vidimo da rezultati obrade u prvobitnoj i $2.5 \mathrm{D}$ skici utječu na prepoznavanje objekata, ali prepoznavanje objekata ne može utjecati na obradu u prvobitnoj skici ili u 2.5D skici. Zbog toga su ove skice kognitivno inpenetrabilne (Raftopoulos, 2001). 


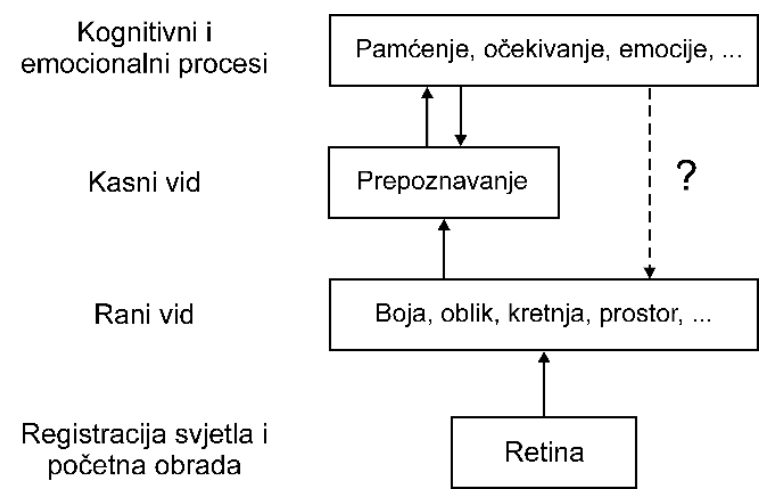

Slika 2. Shematski prikaz odnosa između ranog vida, kasnog vida te kognitivnih i emocionalnih procesa. Temeljno je pitanje preglednog rada postoji li povratna veza označena iscrtanom strelicom.

\section{Argumenti za kognitivnu inpenetrabilnost vida} vida:

Prema Pylyshynu (1999) glavni su argumenti za kognitivnu inpenetrabilnost

1. Perceptivne iluzije ne nestaju nakon što shvatimo da se radi o iluziji. Znanje da naša vidna percepcija ne odgovara stvarnom stanju u svijetu i dalje ne mijenja sadržaj vida. Na primjer, iako smo svjesni da su dvije linije koje uspoređujemo kod Müller-Lyerove iluzije jednako duge, to ne mijenja našu percepciju da je linija koja završava krakovima prema van duža od linije koja završava krakovima prema unutra.

2. Postoje mnoge pravilnosti u vidu koje ovise samo o vidnom podražaju i koje se automatski ekstrahiraju iz njega. Načela prema kojima funkcionira vid nisu ista kao i načela mišljenja i rezoniranja prema kojima funkcionira središnji sustav. Na primjer, kod percepcije su svjetline Gilchrist i sur. (1999) identificirali pravilo prema kojem kao bijelu percipiramo onu površinu koja odašilje najveću količinu svjetla u danom podražaju. Ovakvo je pravilo specifično za percepciju svjetlina jer rješava konkretan računalni problem: kako preslikati skalu relativnih omjera intenziteta svjetla na apsolutnu skalu svjetlina od bijelog do crnog. Ovo se pravilo ne može primijeniti u drugim domenama i ne predstavlja opće pravilo prema kojem može funkcionirati središnji sustav.

3. Neuropsihološka istraživanja pokazuju djelomičnu neovisnost vida od drugih kognitivnih funkcija. Na primjer, ljudi koji imaju vidnu agnoziju, odnosno oštećenje sposobnosti prepoznavanja objekata nemaju istovremeno i problema s općim kognitivnim funkcioniranjem (Farah, 1990). S druge 
strane, ljudi s deficitom u mišljenju i rezoniranju načelno nemaju problema s vidom.

4. Mnogi empirijski nalazi koji se uzimaju kao argument za penetrabilnost vida zapravo se mogu reinterpretirati na način da znanje utječe na neku drugu razinu obrade informacija koja je izvan onoga što se definira kao rani vid. Na primjer, znanje može utjecati na usmjeravanje prostorne pažnje prije početka ranog vida ili može djelovati na procese donošenja odluka o pripadnosti pojedinog podražaja nekoj kategoriji, što se odvija nakon završetka obrade u ranom vidu. Kako bi se preciznije odredilo na koju razinu obrade informacija djeluje neka eksperimentalna manipulacija, potrebna je mnogo preciznija kontrola relevantnih varijabli, na što su posebno upozorili Firestone i Scholl (2016), a o tome će biti više riječi u poglavlju Metodološki aspekti istraživanja penetrabilnosti vida.

Pylyshynove argumente protiv penetrabilnosti vida dalje je razradio Raftopoulos $(2009,2014)$. On se posebno fokusirao na neurofiziološka istraživanja o brzini protoka signala kroz vidni sustav kako bi jasno odredio temporalnu granicu između ranog i kasnog vida. Istraživanja mjerenja vremena latencije odgovora neurona u vidnim kortikalnim centrima upućuju na stvaranje vidne reprezentacije podražaja u tri koraka (Lamme, 2003; Lamme i Roelfsema, 2000; Roelfsema, 2005). Prvi se korak odvija unutar prvih $100 \mathrm{~ms}$ nakon zadavanja podražaja, kada traje prijenos signala od retine preko vidnih kortikalnih područja sve do inferiornoga temporalnog korteksa. Ovaj je prijenos signala nesvjestan i otporan na povratne veze iz viših kortikalnih područja i zato se smatra čistim uzlaznim oblikom prijenosa vidnih informacija. Prvi korak rezultira ekstrahiranjem elementarnih obilježja kao što su boja, orijentacija rubova, pokret i tekstura, koji su važni za kasnije prepoznavanje i kategorizaciju. U drugom koraku, koji se odvija oko $120 \mathrm{~ms}$ nakon zadavanja podražaja, počinju djelovati lateralne projekcije neurona unutar istoga kortikalnog područja, kao i povratne veze u ranija područja poput primarnoga vidnog korteksa. U ovom se koraku formiraju složenije vidne reprezentacije kao što je reprezentacija površina i razdvajanje lika od pozadine. Tek u trećem koraku, koji se odvija između 150 i 200 ms nakon zadavanja podražaja, signali iz frontalnih i prefrontalnih područja te mnemoničkih krugova u hipokampusu počinju modulirati perceptivno procesiranje u vidnom korteksu. Stoga Raftopoulos $(2009,2014)$ tvrdi da je tek treći korak vidnog procesiranja kognitivno penetrabilan, dok prva dva koraka čine procesi koji odgovaraju Marrovu konceptu ranog vida i nisu izravno pod utjecajem kognitivnih procesa.

\section{Nesvjesno zaključivanje nasuprot prirodnim ograničenjima}

Temeljni problem percepcije jest $\mathrm{u}$ tome što nije dovoljno određena samom retinalnom slikom. Naime, ista retinalna slika može biti posljedica različitih situacija 
u okolini i može dovesti do različitih interpretacija. Dakle, vidni sustav mora kreirati reprezentaciju okoline na osnovu djelomičnih informacija. Ovaj je problem vrlo složen i zahtijeva netrivijalna rješenja. Primjerice, živimo u trodimenzionalnom prostoru u kojem je važno odrediti udaljenost od objekata radi lakšeg snalaženja u prostoru. Međutim, slika na retini je dvodimenzionalna, stoga vidni sustav mora rekonstruirati treću dimenziju na osnovu spajanja informacija iz dviju retina. Kako vidni sustav rješava ovaj problem? Klasičan je odgovor ponudio Helmholtz (1867/1924) konceptom nesvjesnog zaključivanja, prema kojem vid rabi skrivene pretpostavke i znanje o vanjskom svijetu pomoću kojih dolazi do perceptivnih zaključaka o najvjerojatnijem stanju u okolini koje je moglo proizvesti danu retinalnu stimulaciju. Pri tome, vid se koristi procesima sličnim zaključivanju i rješavanju problema kako bi sirove retinalne signale pretvorio u percepciju. Ljudi nisu svjesni odvijanja ovih procesa, već samo konačnoga rezultata. Ove su ideje dalje razvili i nadogradili Gregory (1970) i Rock (1983) u okviru konstruktivističke škole mišljenja, koja predstavlja dominantni teorijski pravac u suvremenoj znanosti o vidu (Palmer, 1999). Jedna od implikacija nesvjesnog zaključivanja jest da je vid kognitivno penetrabilan jer je znanje i zaključivanje izravno uključeno u stvaranje vidne reprezentacije. Međutim, Pylyshyn (1999) smatra pogrešnim pripisivati vidu procese zaključivanja i rješavanja problema. Umjesto toga, vid treba promatrati kao složeni sustav za obradu informacija koji radi po svojim specifičnim pravilima.

Alternativno objašnjenje kako riješiti problem konstrukcije vidne reprezentacije na osnovu djelomičnih informacija ponudio je Marr (1982). On smatra da u ranom vidu postoje specijalizirani mehanizmi koji utjelovljuju rješenja zasnovana na prirodnim ograničenjima koja postoje u fizikalnom svijetu. Ovi su mehanizmi evolucijom ugrađeni $u$ vidni sustav $i$ aktiviraju se automatski kada gledamo neki podražaj i ne zahtijevaju procese zaključivanja i rješavanja problema. Pri tome, važno je napomenuti da ovi mehanizmi ne jamče uvijek točnu interpretaciju svih podražaja, nego samo onih koji se najčešće javljaju u danim uvjetima u našoj okolini.

Na primjer, Marr i Poggio (1976) predložili su model stereopsisa koji rješava problem korespondentnosti, odnosno pronalazi korespondentne točke na obje retine i izračunava disparitet među njima. To nije jednostavno jer postoji ogroman broj kombinacija uparivanja, tj. jedna točka u lijevom oku može odgovarati velikom broju točaka u desnom oku.

Kako bi riješili ovaj problem, Marr i Poggio (1976) identificirali su nekoliko prirodnih ograničenja koja odgovaraju karakteristikama okoline, a koja mogu poslužiti vidnom sustavu za lakše pronalaženje parova točaka. Jedno je takvo ograničenje kompatibilnost obilježja prema kojem se mogu uparivati samo slična obilježja jer isti objekt ne može proizvesti bitno drugačiju sliku u oba oka. Nadalje, Marr i Poggio (1976) su pokazali kako se dana ograničenja mogu ugraditi u arhitekturu neuronske mreže u obliku uzoraka ekscitacija i inhibicija neurona. Mreža se sastojala od neurona koji su kodirali različite disparitete točaka u obje retine. Računalne simulacije predložene mreže pokazale su da je ona uspješno pronalazila 
korespondentne točke i na taj način odredila dubinu na osnovu dispariteta dviju retinalnih slika. Dakle, mreža nije trebala posebno eksterno znanje ni procese zaključivanja i rješavanja problema kako bi uparila točke iz obiju retina. Znanje je ugrađeno u samu strukturu mreže poštujući postojeća prirodna ograničenja.

\section{Kognitivna penetrabilnost vida}

\section{Novi pogled}

Koncepti kognitivne inpenetrabilnosti i modularnosti vida u suprotnosti su s eksperimentalnim nalazima nastalima unutar popularnoga znanstvenog pokreta poznatog pod nazivom novi pogled (Bruner, 1957). Prema ovom gledištu kognitivni procesi mogu utjecati na percepciju, stoga je ono što vidimo rezultat interakcije naših vjerovanja, želja, emocija, motivacije i jezika sa sirovim osjetnim informacijama. Bruner i Goodman (1947) su u brojnim eksperimentima pokazali da je percepcija pod utjecajem znanja i vjerovanja promatrača o svijetu koji percipira. Primjerice, siromašna djeca sustavno precjenjuju veličinu novčića u odnosu na bogatiju djecu, a gladni ljudi će prije percipirati hranu ili identificirati riječi povezane s hranom od sitih ljudi. Na osnovu ovakvih nalaza zaključili su da vrijednosti i potrebe pojedinca utječu na sve razine hijerarhijske strukture percepcije i tako mijenjaju način na koji percipiramo svijet.

Slično Helmholtzu (1867/1924) Bruner (1957) smatra da vid određuju dva bitna obilježja: kategorizacija i testiranje hipoteza. Vid se promatra kao proces sličan znanosti u kojem se formuliraju i testiraju hipoteze. Hipoteze se odnose na pripadnost objekta određenoj kategoriji. Ako se hipoteza pokaže pogrešnom, odbacuje se i kreira se nova hipoteza koja se zatim testira s obzirom na dane osjetne podatke. $\mathrm{Na}$ taj se način vid kroz niz ciklusa testiranja i odbacivanja hipoteza postupno približava identitetu objekta, odnosno kategoriji kojoj pripada. Stoga se vid može promatrati i kao oblik rješavanja problema u kojem ulazni signali koji dolaze kroz osjete predstavljaju problem koji treba riješiti. Nedostajući podaci potrebni za rješenje dolaze od silaznih procesa, odnosno znanja, očekivanja, potreba i vjerovanja. Rješenje problema, odnosno krajnji rezultat vida je kategorija kojoj pripada objekt koji se promatra. Iz ovih razmatranja proizlazi da nema razlike između načela po kojima funkcionira vid i načela po kojima funkcionira mišljenje. Popularnost ovog gledišta proizlazi i iz dobrog slaganja s našom intuicijom, odnosno svakodnevnim iskustvom. Na primjer, kada smo gladni, čak i neki neodređeni, neutralni podražaj možemo percipirati kao hranu. Kada smo uplašeni, i bezazleni podražaj kao što je šuštanje lišća na ulici percipiramo kao prijeteći, što je ovjekovječeno u izreci $U$ strahu su velike oči. Također, primjer za penetrabilnost su i mađioničarski trikovi u kojima mađioničar manipulira onim što vidimo tako što kreira lažna očekivanja koja nas iznevjere i zbog toga zabavljaju. 


\section{Teorijski argumenti za penetrabilnost vida}

$\mathrm{U}$ novije je vrijeme pokret novi pogled ponovno aktualan razvojem novih teorijskih konstrukata kao što je prediktivno kodiranje i Bayesijanski modeli percepcije (Clark, 2013; Friston, 2010; Hohwy, 2013; Lupyan, 2015; O'Callaghan, Kveraga, Shine, Adams i Bar, 2017; Vetter i Newen, 2014). Osnovna je ideja potekla od Helmholtza (1867/1924), koji je predložio model eferentnih kopija koje generira motorni sustav kako bi predvidio senzorne posljedice izvršenja motornih naloga. $\mathrm{Na}$ taj način mozak osigurava stabilnu percepciju položaja objekata nakon izvršenja pokreta očiju (Schubotz, 2015). Svrha je prediktivnog kodiranja skraćivanje vremena i smanjenje količine procesnih resursa potrebnih da se obradi ogromna količina senzornih informacija koje neprestano dolaze do naše retine (Huang i Rao, 2011). Koncept prediktivnog kodiranja pretpostavlja da mozak, u svrhu predviđanja kakve će vjerojatno biti nadolazeće senzorne informacije, kontinuirano stvara model vanjskog svijeta i mijenja ga i nadograđuje prema pravilima Bayesijanske statistike (Friston, 2010; Rao i Ballard, 1999).

Model okoline oblikuje se na osnovu prošlih iskustava pohranjenih u pamćenju, kontekstualnih asocijacija kao i senzornih informacija iz drugih osjetnih modaliteta. Naime, objekte opažamo u tipičnim uvjetima u kojima se često pojavljuju zajedno s drugim objektima, a to nam iskustvo omogućava učenje asocijacija među njima. Asocijacije potom postaju bogat izvor informacija kojima se rukovodimo prilikom identifikacije objekta. U slučaju dvosmislenog podražaja informacija o kontekstualnom okruženju olakšat će nam njegovu interpretaciju (Bar, 2004).

Anatomska su osnova za prediktivno kodiranje povratni neuronski putovi od anteriornog temporalnog i posteriornog parijetalnog korteksa prema primarnom vidnom korteksu (Angelucci, Levitt, i Lund, 2002; Bulier, 2001). U V1 uspoređuju se silazni signali koji nose informaciju o predikciji s nadolazećim uzlaznim, odnosno senzornim signalima, a njihovo međusobno neslaganje predstavlja pogrešku predikcije. Informacija o pogrešci prenosi se uzlaznim vezama natrag do viših vidnih centara, gdje se prediktivni model mijenja, odnosno ispravlja sve dok se ne smanji pogreška predikcije. Drugim riječima, više razine povratnim vezama pokušavaju predvidjeti odgovore jedinica na nižim razinama u vidnoj hijerarhiji (Rao i Ballard, 1999).

$\mathrm{Na}$ staničnoj se razini pretpostavlja da su piramidalne stanice na površini korteksa nosioci informacije o veličini pogreške predikcije nastale usporedbom silaznih i uzlaznih signala, a da su piramidalne stanice u dubljim slojevima korteksa nosioci silaznih predikcija (Friston, 2008; Mumford, 1992). Nadalje, pretpostavlja se da pažnja omogućuje fleksibilno kontroliranje tolerancije s obzirom na preciznost usporedbi i pogrešaka predikcije. Pri tome, pažnja ostvaruje svoj učinak na neurone putem modulacije neurotransmisije acetilkolinom ili putem brze sinkronizacije oscilatorne aktivnosti (Feldman i Friston, 2010). 
Važna implikacija prediktivnog kodiranja jest da je vid interaktivan, dvosmjeran proces nadopunjavanja uzlaznih i silaznih signala. Drugim riječima, mozak nikada ne percipira okolinu kao praznu sliku, nego uvijek kreće od neke pretpostavke o tome kako bi okolina mogla izgledati. Friston (2010) navodi da mozak nastoji što je više moguće smanjiti iznenađenje, odnosno pogrešku predikcije te zbog toga stalno procjenjuje stanje u okolini aktivnim zaključivanjem, odnosno prediktivnim kodovima koji silaznim putovima ponderiraju uzorke ekscitacije u nižim vidnim centrima prema načelima Bayesijanske statistike. Stoga se model prediktivnog kodiranja može smatrati oblikom kognitivne penetrabilnosti vida (Lupyan, 2015; Vetter i Newen, 2014). Međutim, Macpherson (2017) upozorava da je moguće kreirati različite verzije modela prediktivnog kodiranja, među kojima i one koji ne podrazumijevaju penetrabilnost vida.

\section{Neuroznanstveni argumenti za penetrabilnost vida}

Istraživanja funkcionalnim oslikavanjem mozga magnetskom rezonancijom (fMRI) pokazala su da znanje o objektu može kreirati očekivanja koja mijenjaju aktivnost $\mathrm{u}$ vidnim centrima koji reprezentiraju elementarna perceptivna obilježja kao što su boja i oblik. Vandenbroucke, Fahrenfort, Meuwese, Scholte i Lamme (2016) prikazivali su ispitanicima nijansu žute boje koja se po svom tonalitetu nalazi između crvene i zelene. Žuta boja prikazana je ili na objektu koji je tipično crven (npr. rajčica), objektu koji je tipično zelen (npr. krastavac) ili potpuno nepoznatom objektu. Koristeći tehniku dekodiranja neuronskih signala pokazali su da mogu predvidjeti gledaju li ispitanici žutu boju na tipično crvenom ili tipično zelenom objektu samo na osnovu neuronskog odgovora na čistu crvenu ili zelenu boju u kortikalnom području V4 za koje se zna da ima važnu ulogu u reprezentaciji boja. Drugim riječima, neuronski odgovor na žutu boju bio je pomaknut prema crvenoj boji kada su je ispitanici gledali na rajčici ili prema zelenoj boji kada su je gledali na krastavcu. Slično tome, Kok, Brouwer, van Gerven i de Lange (2013) pokazali su da kreiranjem očekivanja o smjeru kretanja skupine točkica dolazi do promjene aktivnosti u ranim razinama vidne hijerarhije koja uključuju V1 i V2. Zanimljivo je da nije došlo do modulacije aktivnosti u V5 (MT) području, što bi se očekivalo s obzirom na spoznaje o reprezentaciji kretanja upravo u tom području.

Socijalno i emocionalno znanje također može penetrirati u vid, na što upućuju istraživanja percepcije lica EEG-om i fMRI-om, što ima ključnu ulogu u socijalnim interakcijama. Kada ispitanici gledaju lica pripadnika iste socijalne grupe kojoj i sami pripadaju (iste rase ili arbitrarno formirane grupe), dolazi do jače aktivacije u fuziformnom girusu nego kada gledaju lica pripadnika druge grupe (Golby, Gabrieli, Chiao i Eberhardt, 2001; Van Bavel, Packer i Cunningham, 2008). U istom smjeru, percepcija lica iz iste grupe dovodi do pojačanog N170 vala, koji se smatra najranijom komponentom vidnog procesiranja lica (Ratner i Amodio, 2013). Nadalje, afektivna vrijednost podražaja utječe na vid vrlo rano, što se vidi iz 
moduliranja ERP signala u rasponu od 120 do $160 \mathrm{~ms}$ od zadavanja podražaja (Olofsson, Nordin, Sequeira i Polich, 2008). Ovo ima veliku važnost za preživljavanje jer signalizira jedinki prilaženje objektu ili njegovo izbjegavanje (Barrett i Bliss-Moreau, 2009). Kveraga i sur. (2015) su pokazali da emocionalne predikcije imaju važnu ulogu u brzom prepoznavanju prijetnje. Naime, otkrili su da se bihevioralni odgovor, kao i neuronska reakcija na prijetnju mijenja ovisno o tome radi li se o direktnoj ili indirektnoj prijetnji (gleda li prijeteća životinja izravno u opažača ili ne), što upućuje na zaključak o integraciji afektivne informacije s vidnom u cilju što brže i točnije interpretacije prijeteće situacije.

Kao glavni je izvor silaznih signala, odnosno predikcija identificiran orbitofrontalni korteks. To je dio frontalnog režnja koji je povezan s nizom važnih funkcija, od ponašajne inhibicije i emocionalne regulacije pa sve do reprezentacije potkrepljenja (nagrade) i donošenja odluka (O'Callaghan i sur., 2017). Njegova uloga u prepoznavanju objekata istraživana je selektivnom stimulacijom ventralnog ili dorzalnog puta. Podražaji niske prostorne frekvencije primarno aktiviraju dorzalni put koji brzo aktivira orbitofrontalni korteks, a koji zatim šalje povratne silazne signale prema fuziformnom girusu u ventralnom putu. $\mathrm{S}$ druge strane, podražaji visoke prostorne frekvencije izravno stimuliraju fuziformni girus uzlaznim vezama unutar ventralnog puta (Kveraga, Boshyan i Bar, 2007). Sličnu su brzu aktivaciju orbitofrontalnog korteksa koja prethodi aktivaciji temporalnog režnja, odnosno ventralnog puta pokazala istraživanja u kojima su ispitanici procjenjivali koherentnost degradiranog podražaja (Horr, Braun i Volz, 2014) ili razlikovali lica od ne-lica (Summerfield, Lepsien, Gitelman, Mesulam i Nobre, 2006). Ovi rezultati upućuju na zaključak da orbitofrontalni korteks daje grubu inicijalnu procjenu kategorije kojoj objekt pripada, a ta procjena silaznim vezama usmjerava i ubrzava prepoznavanje objekta u temporalnom režnju. Također, orbitofrontalni korteks igra važnu ulogu i u brzoj obradi afektivne vrijednosti podražaja (Pessoa i Adolphs, 2010).

O'Callaghan i sur. (2017) smatraju da su i vidne halucinacije primjer za kognitivnu penetrabilnosti ranog vida. Analiza sadržaja halucinacija pokazuje da se u njima često javljaju poznati ljudi, lica, objekti ili kućni ljubimci (Barnes i David, 2001). Nadalje, učestalost i jačina halucinacija povezana je s raspoloženjem i fiziološkim stanjem kao što su stres ili umor (Waters i sur., 2014). U okviru modela prediktivnog kodiranja halucinacije su rezultat pretjerane aktivacije kontekstualnih asocijacija, autobiografskih sjećanja i emocionalnih stanja koja pomiču balans između uzlaznih i silaznih procesa na način da daju veći ponder silaznim procesima. Drugim riječima, internalno generirane predikcije kod halucinacija dominiraju vidom usprkos suprotnim senzornim signalima. Potvrdu za ovu pretpostavku daju istraživanja koja pokazuju abnormalno pojačanu aktivnost upravo u kortikalnim centrima, poput orbitofrontalnog korteksa, koji predstavljaju izvor silaznih signala tijekom normalne vidne percepcije (Shine, O'Callaghan, Halliday i Lewis, 2014). 


\section{Bihevioralni nalazi za penetrabilnost vida}

U zadnjih dvadesetak godina objavljen je velik broj istraživanja koja upućuju na kognitivnu penetrabilnost vida. Detaljan su popis ovih studija dali Firestone i Scholl (2016). U nastavku smo odabrali i detaljnije prikazali nekoliko studija koje su izazvale najviše polemika te koje su motivirale raspravu o metodološkim i interpretacijskim problemima, o kojima će biti više riječi u zasebnom poglavlju.

Bhalla i Proffitt (1999) ispitivali su odnos percepcije nagiba brda i fiziološkog potencijala pojedinca. U četiri su eksperimenta pokazali da se brda čine strmijima kada su ljudi: opterećeni nošenjem teškog ruksaka, umorni nakon dugog trčanja, slabe tjelesne kondicije i stariji ili lošijeg zdravlja. U eksperimentu s nošenjem teškog ruksaka ispitanici su davali tri vrste procjene nagiba brda: verbalne, vidne i taktilne. Zanimljiv je nalaz da se verbalno i vidno precjenjivanje nagiba brda povećavalo opadanjem fiziološkog potencijala zbog opterećenja ruksakom, ali su taktilne procjene ostale točne. Bhalla i Proffitt (1999) su iz ovoga zaključili da je motorički odgovor nesvjestan i daje točnije procjene nagiba, čak i nakon verbalnih uputa o kutu dok ga ispitanik gleda.

Witt, Proffitt i Epstein (2004) proveli su nekoliko eksperimenata u kojima su ispitivali ovisi li efekt fizičkog napora na percipiranu udaljenost predmeta o predviđanju ispitanikove uspješnosti o vlastitoj izvedbi zadatka. Dobiveni rezultati sugeriraju da je percipirana udaljenost $u$ funkciji stvarne udaljenosti koja je određena optičkim varijablama, ali i namjerom za akcijom i naporom povezanim $\mathrm{s}$ tom namjerom. Tako, primjerice, bacanje teške lopte na metu u odnosu na laku loptu povećava procjene udaljenosti te mete. Nadalje, pokazalo se da konzumiranje glukoze nakon gladovanja dovodi do toga da se nagib brda percipira manjim (Schnall, Zadra i Proffitt, 2010), a da se udaljenosti percipiraju kraćima (Cole, Balcetis i Dunning, 2013) nego nakon konzumacije nekaloričnog sladila. Isto tako, negativno raspoloženje čini brdo strmijim u odnosu na pozivno raspoloženje (Riener, Stefanucci, Proffitt i Clore, 2011).

Kognitivni i emocionalni utjecaji na percepciju nisu ograničeni samo na percepciju spacijalnih obilježja kao što su nagib ili udaljenost nego su otkriveni i u području percepcije svjetline i boje. Goldstone (1995) je ispitivao utjecaj kategorizacije na percepciju boje. Ispitanici su najprije učili povezati brojke i slova s određenom bojom u rasponu od crvene do ljubičaste. Pri tome su slova sustavno prikazivana u crvenijim tonalitetima, a brojke u plavljim (ili obrnuto za drugu grupu ispitanika). Ključni je dio eksperimenta bio u tome da su jedno slovo (E) i jedna brojka (8) uvijek prikazivani u istoj boji, koja je po svom tonalitetu bila između crvene i ljubičaste. $U$ drugom su dijelu istraživanja ispitanici podešavali boju brojki i slova. Pokazalo se da je kategorija objekta utjecala na prosudbu boje. Ispitanici su slovo E sustavno procjenjivali crvenijim nego brojku osam (8) (odnosno u drugoj grupi ispitanika plavljim). 
Banerjee, Chatterjee i Sinha (2012) ispitivali su može li dosjećanje (ne)etičnih djela utjecati na percepciju svjetline. Zadatak je ispitanika bio prisjetiti se (ne)etičnih djela iz vlastite prošlosti i detaljno ih opisati uz prateće emocionalne doživljaje. Nakon toga su trebali na numeričkoj skali od jedan do sedam procijeniti stupanj svjetline sobe u kojoj su boravili. Rezultati su pokazali da su ispitanici koji su opisali neetična djela sobu procijenili tamnijom u odnosu na ispitanike koje su opisali etična djela. Slično tome, Song, Vonasch, Meier i Bargh (2012) su ispitivali procjenjuju li ljudi nasmiješena lica svjetlijima u odnosu na namrštena lica. Pretpostavili su da metaforički izrazi poput svijetli osmijeh, koji postoji u mnogim jezicima kao što su engleski, njemački, talijanski, kineski ili ruski, imaju podlogu u konceptualnom preslikavanju facijalnih ekspresija na percepciju svjetline. Drugim riječima, pretpostavili su da je osmijeh, odnosno pozitivno raspoloženje, povezano sa svijetlim nijansama, dok je mrštenje, odnosno negativno raspoloženje, povezano s tamnijim nijansama boje. Ispitanicima su prezentirana po dva shematska lica, jedno nasmiješeno i jedno namršteno, pri čemu su oba lica bila izjednačena po svjetlini. $U$ jednom je eksperimentu zadatak ispitanika bio da procijene koje je lice svjetlije, a u drugom da daju apsolutnu procjenu svjetline na numeričkoj skali. Rezultati su pokazali da ispitanici nasmiješeno lice procjenjuju svjetlijim od namrštenog lica neovisno o vrsti procjene koju daju. Isti je efekt dobiven i sa stvarnim licima čime je povećana ekološka valjanost ovog nalaza. Štoviše, razlika u procjenama svjetline bila je veća za stvarna lica nego za shematska lica.

\section{Metodološki aspekti istraživanja penetrabilnosti vida}

Problem je s originalnim istraživanjima Brunera i njegovih suradnika (1947), koja su inspirirala pokret novi pogled $\mathrm{u}$ percepciji, u tome što nisu kasnije replicirana. Na primjer, pokazalo se da utjecaj socioekonomskog statusa na procjenu veličine novčića postoji samo kada se procjena daje na osnovu dosjećanja, a ne kada se on direktno gleda. Nadalje, neki vrijedni objekti ili simboli nisu izazivali isti efekt kao novčići u originalnoj studiji. Također, otkriven je velik broj moderirajućih varijabli, što je sve upućivalo na nedovoljnu kontrolu i nedostatnu metodološku rigoroznost (Firestone i Scholl, 2016).

Firestone i Scholl (2016) smatraju da se slični problemi javljaju i u suvremenim istraživanjima. Stoga su napravili detaljnu analizu metodologije i interpretacije rezultata istraživanja koja idu u prilog penetrabilnosti vida te zaključili da se isti efekti mogu objasniti i bez pozivanja na utjecaj kognicije ili emocija. Najvažniji je doprinos njihova rada $u$ isticanju zahtjeva za poboljšanjem znanstvene metodologije i kontrole u provedbi istraživanja. Konkretno, izdvojili su šest metodoloških i interpretacijskih poteškoća koja otežavaju donošenje suda o kognitivnoj penetrabilnosti vida i koje će morati uzeti u obzir sva buduća istraživanja. To su: istraživačka strategija usmjerena na potvrđivanje hipoteza, percepcija nasuprot prosudbe, zahtjevi eksperimenta i pristranost pri odgovaranju, razlike u 
elementarnim obilježjima, periferni efekti pažnje i pamćenje nasuprot prepoznavanju.

\section{Istraživačka strategija usmjerena na potvrđivanje hipoteza}

Eksperimentalna se hipoteza može provjeriti na dva načina: pronalaženjem efekta koji je u skladu s teorijom i odsustvom efekta kada teorija predviđa njegovu odsutnost. U većini je istraživanja o kognitivnoj penetrabilnosti korišten samo prvi pristup. Stoga Firestone i Scholl (2016) smatraju da nedostaje mnogo potencijalno važnih nalaza koji mogu pomoći u razrješenju debate o kognitivnoj (in)penetrabilnosti vida. Tek se u novije vrijeme počeo koristiti i drugi način provjere suprotstavljenih teorija testiranjem jedinstvenih opovrgavajucih hipoteza.

Konkretan je primjer razlikovanja potvrđujućih i opovrgavajućih hipoteza vidljiv u istraživanjima Firestonea i Scholla (2014), koji su bili inspirirani zanimljivom zgodom iz povijesti umjetnosti poznatom pod nazivom El Grecova pogreška. El Greco je bio slavni španjolski slikar iz razdoblja manirizma koji je slikao neobično izduljene ljudske figure. Analizirajući njegove slike te kako bi pokušali objasnili izobličenja likova, povjesničari umjetnosti krivo su pretpostavili da je El Greco bolovao od posebno jakog oblika astigmatizma. Radi se o urođenoj deformaciji rožnice zbog koje je cijeli svijet percipirao izduljeno, pa je stoga tako i slikao. Međutim, nekoliko je istraživača argumentiralo da se radi o pogrešnom zaključivanju i da El Greco najvjerojatnije nije svijet doživljavao na izduljen način. Naime, u tom bi slučaju i njegova slikarska platna trebala biti izduljena, pa zapravo tragovi pretpostavljenih distorzija ne bi trebali biti vidljivi na samim slikama (Anstis, 2002; Firestone, 2013). Slična se pogreška javlja i prilikom interpretacije nalaza o silaznim procesima. Stoga Firestone i Scholl (2016) preporučuju da se u budućim istraživanjima u obzir uzmu i potvrđujuće i opovrgavajuće hipoteze.

U replikaciji istraživanja o utjecaju negativnog ili pozitivnog raspoloženja na percepciju svjetline Firestone i Scholl (2014) su tražili od ispitanika da procjenu svjetline sobe daju na skali nijansi sivih tonova, a ne na numeričkoj skali. Pri tome su očekivali da će se utjecaj raspoloženja na percepciju svjetline poništiti. Ako svijet zaista izgleda tamnije (ili svjetlije) nakon indukcije negativnog (ili pozitivnog) raspoloženja, tada će i skala s nijansama sive boje također potamniti (ili posvijetliti) do iste razine kao i soba, pa će ispitanici birati istu nijansu sive, odnosno neće biti razlike u procjenama svjetline u uvjetu pozitivnog i negativnog raspoloženja. Međutim, razlika u procjenama svjetline pojavila se i u ovom slučaju. Dakle, efekt se pojavio čak i u situaciji kada nije trebao, što upućuje na važnost formuliranja i ispitivanja jedinstvenih opovrgavajućih predviđanja. Drugim riječima, efekt koji su dobili Banerjee i sur. (2012) ne može biti posljedica utjecaja emocija na percepciju, nego na neki drugi proces. Firestone i Scholl (2014) također smatraju da su i rezultati istraživanja utjecaja kategorizacije na percepciju boje koje je dobio Goldstone (1995) također posljedica El Grecove pogreške. Naime, uočili su da je u njegovu istraživanju 
podražaj čiju su boju ispitanici podešavali zapravo bio kopija ciljnog slova. Dakle, ispitanici su istovremeno gledali dva podražaja iste boje. Ako je kategorijalno znanje djelovalo na jedan podražaj, trebalo je imati isti utjecaj i na drugi, pa bi se efekti opet trebali međusobno isključiti. Budući da je razlika u procjeni boje ipak dobivena, ona upućuje na to da nije riječ o perceptivnom efektu kao i u prethodnom istraživanju.

\section{Percepcija nasuprot prosudbe}

Budući da je teško odrediti granicu između kognicije i vida, često nije jasno je li ono što vidimo posljedica nekoga kognitivnog stanja ili su naši zaključci ili mišljenja posljedica onoga što vidimo. Npr. možemo percipirati boju ili veličinu nekog objekta (cipele), ali možemo samo prosuđivati o njegovoj skupoći, udobnosti i sl. Iz ovog je razloga moguće da su rezultati u istraživanjima o kognitivnoj penetrabilnosti posljedica djelovanja silaznih procesa na prosudbu, a ne na vid. Stoga će buduća istraživanja morati uzeti u obzir razliku između vida i prosudbe te ih empirijski razdvojiti kako bi se izbjegle krive interpretacije nalaza.

Kao primjer ovog problema mogu se navesti rezultati koje su dobili Witt i sur. (2004) o utjecaju fizičkog napora na percepciju udaljenosti mete. Alternativno objašnjenje ovog nalaza jest da su ispitanici prilikom davanja odgovora jednostavno uzeli u obzir i neperceptivne faktore kao što je težina lopte i da nije došlo do stvarne promjene u percepciji udaljenosti. U skladu s tom interpretacijom Woods, Philbeck i Danoff (2009) su odvojili vidnu percepciju od prosudbe tako da su ispitanicima dali detaljne upute o tome kako da daju svoje odgovore. Naime, ispitanici su morali odgovoriti koliko im daleko objekt stvarno izgleda i da se pri tome potrude isključiti sve druge ometajuće varijable zbog kojih imaju osjećaj da se meta nalazi na nekoj drugoj udaljenosti te da se potrude zanemariti taj osjećaj udaljenosti mete. Pokazalo se da se uz ovakvu uputu efekt težine lopte gubi, što znači da su rezultati koje su dobili Witt i sur. (2004) ipak odražavali mišljenje, odnosno procjenu ispitanika o udaljenosti, a ne kako su tu udaljenost doista percipirali. Međutim, Schnall (2017) smatra da Firestone i Scholl (2016) ne uzimaju u obzir ključne procese koji oblikuju prosudbu: nemogućnost čovjeka da introspektivno pristupi razlozima u podlozi svojih prosudbi, dinamiku razgovora u kontekstu eksperimentalnih istraživanja $i$ pogrešne atribucije. Prema njoj perceptivni procesi funkcioniraju kao i procesi prosudbe jer nisu dostupni svijesti i služe adaptivnom funkcioniranju.

\section{Zahtjevi eksperimenta i pristranost pri odgovaranju}

Zahtjevi zadatka predstavljaju važnu prijetnju unutrašnjoj valjanosti eksperimentalnih istraživanja (Shaughnessy, Zechmeister i Zechmeister, 2012). Naime, sva se istraživanja u psihologiji provode u socijalnom okruženju te uvijek postoji određena interakcija između eksperimentatora i ispitanika. Pri tome, ispitanici nisu pasivni sudionici, nego se aktivno trude shvatiti pravu svrhu eksperimentalne manipulacije. Također, trude se biti dobri ispitanici, odnosno usklađuju svoje 
ponašanje i odgovore $s$ onim što oni misle da je prava svrha istraživanja kako bi ugodili eksperimentatoru. Zbog toga je potrebno uložiti velik trud kako bi se sakrili svi znakovi koji upućuju na hipotezu istraživanja. Klein i sur. (2012) upozoravaju da se u novijim istraživanjima sve manje pažnje posvećuje ovom pitanju što otežava otkivanje stvarnih efekata i pridonosi problemu replikabilnosti psihologijskih istraživanja.

Kao primjer toga možemo navesti istraživanje koje su proveli Bhalla i Proffitt (1999) o utjecaju fizičkog napora na percepciju nagiba brda. Naime, moguće je da ispitanici ne doživljavaju brdo strmijim zbog nošenja teškog ruksaka, nego prilagođavaju svoje odgovore kako bi udovoljili očekivanjima eksperimentatora. U skladu s tom interpretacijom Durgin i sur. (2009) pokazali su da je efekt ruksaka nestao u situaciji kada je ispitanicima dano uvjerljivo (ali lažno) objašnjenje o svrsi nošenja ruksaka. Konkretnije, jednoj je grupi ispitanika objašnjeno da u ruksaku nose elektromiografsku opremu koja služi za nadgledanje mišića gležnja. U tom uvjetu procjene nagiba brda nisu se razlikovale od kontrolne grupe koja nije nosila ruksak. Nadalje, ispitanici su nakon mjerenja dali svoje mišljenje o provedenom istraživanju te je dio ispitanika naveo očekivanje da će nošenje ruksaka promijeniti percepciju nagiba. Dodatna je analiza pokazala da se efekt ruksaka pojavio upravo kod onih ispitanika koji su bili svjesni hipoteze istraživanja. U sljedećem su istraživanju Durgin, Klein, Spiegel, Strawser i Williams (2012) od ispitanika najprije tražili da daju procjene nagiba brda, a zatim su im postavili nekoliko pitanja o tome koliko je težak ruksak te je li ruksak utjecao na njihovu procjenu nagiba. Nakon toga su ponovno tražili od ispitanika da daju procjene nagiba brda i pokazalo se da se efekt ruksaka izgubio nakon druge procjene. Iz toga možemo zaključiti da je u istraživanjima kognitivne penetrabilnosti vida važno razuvjeriti ispitanike nakon provedenog istraživanja, odnosno objasniti im pravu svrhu istraživanja.

\section{Razlike u elementarnim obilježjima}

Pri osmišljavanju nacrta istraživanja potrebno je obratiti pažnju i na manipulaciju podražajima u eksperimentalnim uvjetima. Na primjer, utjecaj uzbuđenja na spacijalnu percepciju možemo provjeriti usporedbom grupa visoke i niske razine uzbuđenja na percepciju istog podražaja ili možemo izmjeriti kako ispitanici percipiraju udaljenost uzbudljivog i neuzbudljivog podražaja. Iako oba pristupa imaju prednosti i nedostatke, jedna je od poteškoća pri manipulaciji podražajima u eksperimentalnim uvjetima mogućnost da je namjeravana silazna manipulacija pomiješana $\mathrm{s}$ promjenama u fizičkoj (uzlaznoj) razini obilježja podražaja i da te suptilne razlike na uzlaznoj razini mogu biti odgovorne za izmjerene razlike u eksperimentalnim uvjetima. Firestone i Scholl (2016) smatraju važnim razdvojiti djelovanje silaznih od uzlaznih varijabli na način da se primijeni silazni faktor, a eliminira uzlazni faktor, ili obrnuto. Primjerice, Levin i Banaji (2006) su pokazali da lica Afroamerikanaca izgledaju tamnije od bijelih lica čak i kada se 
izjednače po prosječnoj svjetlini, što upućuje na djelovanje silaznog faktora znanja o rasi. S druge strane, Firestone i Scholl (2016) replicirali su ovo istraživanje sa zamagljenim verzijama lica kako bi se eliminirala informacija o rasi, a istaknule fizičke razlike na uzlaznoj razini. Pokazalo se da je nakon zamagljivanja većina ispitanika izjavila da su oba lica iste rase (pa čak i da je riječ o istoj osobi), ali su i dalje zamagljeno crno lice procjenjivali tamnijim od zamagljenog bijelog lica, što upućuje na djelovanje neke uzlazne varijable, a ne silazne varijable kao što je rasa. Međutim, Baker i Levin (2016) su zaključili da su Firestone i Scholl (2015a) podcijenili sposobnost ispitanika da detektira rasu na zamagljenoj slici jer je pitanje o rasi bilo otvorenog tipa. Kada se umjesto pitanja otvorenog tipa rabi metoda prisilnog izbora, pokazalo se da je 75-80\% ispitanika točno odredilo rasu. Stoga su potrebna daljnja istraživanja kako bi se razriješilo pitanje mogu li i u kojim uvjetima ispitanici detektirati rasu na zamagljenim slikama. U svakom slučaju, sva buduća istraživanja morat će posvetiti mnogo više pažnje kontroli fizičkih karakteristika podražaja.

\section{Efekti usmjeravanja pažnje}

Selektivna je pažnja blisko povezana s vidom jer usmjeravanjem pažnje možemo promijeniti ono što vidimo, pa čak i naglasiti neke objekte i učiniti ih jasnijima. Mijenjanje onoga što vidimo na način da selektivno odabiremo različite lokacije slično je mijenjanju onoga što vidimo pokretima očiju jer u oba slučaja sami odabiremo ulaz u vid. Međutim, u oba je slučaja utjecaj pažnje nezavisan od razloga za usmjeravanje pažnje, odnosno pažnja nije osjetljiva na sadržaj te namjere ili vjerovanja, pa se takav utjecaj ne može smatrati kognitivnom penetracijom vida (Firestone i Scholl, 2016). S druge strane, Lupyan (2017a) smatra da neki drugi oblici pažnje, kao što su pažnja usmjerena na obilježja ili na semantičke kategorije, doista mijenjaju sadržaj vida na način da mijenjaju izgled objekta. Pri tome je ponudio nekoliko demonstracija u kojima dodatna informacija o tome što se nalazi na slikama bitno mijenja percepciju slike (iako bi zagovornici teze o inpenetrabilnosti vida rekli da mijenja interpretaciju, a ne percepciju slike).

Stoga je važno u budućim istraživanjima kontrolirati ili izmjeriti efekt usmjeravanja spacijalne pažnje kako bi ga se razlikovalo od drugih silaznih procesa. Također, važno će biti razlučiti ima li pažnja usmjerena na obilježja ili na semantičke kategorije drugačiji utjecaj na vid u odnosu na spacijalnu pažnju. Na primjer, istraživanja o dvosmislenim slikama (npr. Neckerova kocka ili slika patka-zec) pokazala su da ispitanici mogu voljnom kontrolom odlučiti koju će od dvije interpretacije percipirati, što bi se moglo interpretirati kao argument za penetrabilnost vida (Churchland, 1988). Naknadna su istraživanja pokazala da se ovaj efekt zapravo svodi na usmjeravanje spacijalne pažnje na različite dijelove slike koji dobivaju prednost u obradi i rezultiraju preferiranjem jedne interpretacije (Long i Toppino, 2004). S druge strane, ispitanici izvještavaju o dužem zadržavanju one interpretacije koja im je poznatija. Razlika u dužini zadržavanja jedne interpretacije nestaje ako se 
podražaj zarotira za $180^{\circ}$ (Peterson, 1994; Peterson i Gibson, 1994; Peterson, Harvey i Weidenbacher, 1991; Vecera i Farah, 1997). Ova istraživanja upućuju na zaključak da prepoznavanje objekta, odnosno prethodno znanje može izravno usmjeravati proces razdvajanja lika od pozadine, koji se smatra dijelom ranog vida. Buduća istraživanja moraju razjasniti je li i ovaj efekt zapravo posredovan usmjeravanjem spacijalne pažnje ili predstavlja dokaz za kognitivnu penetrabilnost vida.

\section{Pamćenje i prepoznavanje}

$\mathrm{U}$ mnogim se istraživanjima efekt kognitivne penetracije miješa $\mathrm{s}$ prepoznavanjem podražaja. Na primjer, pridjeljivanje jezičnih oznaka jednostavnim oblicima ubrzava vrijeme vidne pretrage i drugih zadataka prepoznavanja. Međutim, prepoznavanje osim vidnog procesiranja uključuje i pamćenje kako bi se dani vidni podražaj usporedio sa zapamćenom reprezentacijom. Budući da vidno prepoznavanje uključuje i percepciju i pamćenje, preporuka je za buduća istraživanja razlikovati ova dva procesa (jer efekti pamćenja nemaju implikacije za prirodu percepcije) ako želimo govoriti o efektima kognitivne penetracije u vid (Firestone i Scholl, 2016).

Gantman i Van Bavel (2014) ispitivali su efekt vidnog iskakanja moralno važnih riječi (engl. moral pop-out). Ispitanicima su tahistoskopski prezentirane smislene i besmislene riječi za koje su morali odlučiti u koju od te dvije kategorije pripadaju (zadatak leksičke odluke). Neke su riječi bile moralno važne (npr. ilegalan), a neke moralno nevažne (npr. ograničen). Rezultati su pokazali da ispitanici točnije identificiraju moralno važne od moralno nevažnih riječi. Međutim, moralno važne riječi bile su međusobno semantički povezane. Zbog toga je moguće da su moralne riječi stvorile pripremu jedna za drugu i da su se lakše prepoznavale zbog olakšanog doziva iz semantičkog pamćenja, a ne zbog utjecaja na vid. Stoga se utjecaj semantičke pripreme (engl. priming) ne može smatrati primjerom kognitivne penetrabilnosti vida jer bilo koja kategorija riječi može u sličnim uvjetima biti lakše detektirana. Upravo to su demonstrirali Firestone i Scholl (2015b) u eksperimentu u kojem su dobili isti efekt, odnosno točnije detekcije riječi koristeći kao podražaje riječi povezane s trivijalnom arbitrarnom kategorijom kao što je odijevanje. U drugom su eksperimentu upotrebljavali riječi povezane s prometom i opet su dobili isti efekt. Dobiveni rezultati sugeriraju da je semantička povezanost riječi ključan faktor u podlozi efekta koji su dobili Gantman i Van Bavel (2014). Stoga se može zaključiti da pamćenje, a ne vidna percepcija poboljšava detekciju riječi povezanih s moralom (kao i s bilo kojom drugom kategorijom riječi). 


\section{Zaključak}

Na osnovu prikazanih teorijskih argumenata kao i empirijskih podataka koji im idu u prilog može se jedino zaključiti da nije postignut konsenzus o tome postoji li utjecaj kognicije i emocija na vid. U teorijskom je smislu važno razjasniti ulogu silaznog procesiranja i povratnih veza u vidnom korteksu. Prediktivno kodiranje i Bayesijanski modeli nisu jedini računalni modeli vidne percepcije. Alternativni pristup razumijevanju uloge silaznih procesa pružio je Grossberg (2013) u okviru teorije adaptivne rezonance. Grossberg $(1999,2017)$ je predložio hipotezu prema kojoj su svjesna perceptivna stanja rezultat rezonance, odnosno slaganja između uzlaznih i silaznih signala. Kada slaganja nema, silazni se utjecaji brišu, odnosno inhibiraju te je daljnje procesiranje vođeno isključivo uzlaznim signalima. Iz toga proizlazi da je vid zaštićen od kognitivnog utjecaja. Međutim, nije jasno kako bi ova teorija objasnila nalaze koji se navode u prilog kognitivnoj penetrabilnosti vida. Stoga su potrebna daljnja istraživanja, posebno simulacijske studije koje bi objasnile na kojoj razini obrade informacija u okviru teorije adaptivne rezonance dolazi do djelovanja kognicije i emocija.

U budućim je empirijskim istraživanjima potrebno uvažiti preporuke koje su predložili Firestone i Scholl (2016) kako bi se razlučilo stvarno djelovanje kognicije i emocija na vid od djelovanja drugih (ometajućih) faktora koji su prisutni u eksperimentu. Zanimljivo je kako lako nestaju efekti koji se uzimaju kao argument za penetrabilnost vida kada se sakrije prava svrha eksperimentalne manipulacije (Firestone i Scholl, 2017). S druge strane, ostaje otvoreno pitanje u kojoj je mjeri uopće moguće razdvojiti vidnu percepciju od interpretacija procjena i prosudbi, o čemu postoje podijeljena mišljenja (Durgin, 2017; Schnall, 2017). Nije dovoljno ostati samo na teorijskim raspravama o ovoj distinkciji nego i u eksperimentima osigurati da subjektivne procjene ispitanika ne budu kontaminirane prosudbama nakon završenoga perceptivnog procesa.

Na kraju, možemo zaključiti da za sad nema čvrstih argumenata za penetrabilnost vida jer se gotovo svi bihevioralni nalazi koji se uzimaju kao podrška ovoj ideji zapravo mogu pripisati ili djelovanju neperceptivnih faktora (prosudba, pamćenje, prepoznavanje i usmjeravanje pažnje) ili nedovoljnoj eksperimentalnoj kontroli, što uključuje kontrolu fizičkih obilježja podražaja, kao i kontrolu ispitanikovih pretpostavki o pravoj hipotezi istraživanja. Stoga ostaje otvoreno istraživačko pitanje može li se kreirati istraživanje u kojem će se nedvosmisleno izolirati izravni utjecaj kognicije i/ili emocija na vid. 


\section{Literatura}

Adelson, E. H. i Bergen, J. R. (1991). The plenoptic function and the elements of early vision. U: M. Landy i J. A. Movshon (Ur.), Computational models of visual processing (str. 320). Cambridge, MA: MIT Press.

Angelucci, A., Levitt, J. B. i Lund, J. S. (2002). Anatomical origins of the classical receptive field and modulatory surround field of single neurons in macaque visual cortical area V1. Progress in Brain Research, 136, 373-388.

Anstis, S. (2002). Was El Greco astigmatic? Leonardo, 35, 208-208. doi:10.1162/ 00240940252940612

Baker, L. J. i Levin, D. T. (2016). The face-race lightness illusion is not driven by low-level stimulus properties: An empirical reply to Firestone and Scholl (2014). Psychonomic Bulletin \& Review, 23(6), 1989-1995. doi:10.3758/s13423-016-1048-z

Balcetis, E. (2016). Approach and avoidance as organizing structures for motivated distance perception. Emotion Review, 8(2), 115-128. doi:10.1177/1754073915586225

Banerjee, P., Chatterjee, P. i Sinha, J. (2012). Is it light or dark? Recalling moral behavior changes perception of brightness. Psychological Science, 23, 407-409. doi:10.1177/ 0956797611432497

Bar, M. (2004). Visual objects in context. Nature Reviews Neuroscience, 5(8), 617-629.

Barnes, J. i David, A. S. (2001). Visual hallucinations in Parkinson's disease: A review and phenomenological survey. Journal of Neurology, Neurosurgery \& Psychiatry, 70, 727733.

Barrett, L. F. i Bliss-Moreau, E. (2009). Affect as a psychological primitive. Advances in Experimental Social Psychology, 41, 167-218. doi:10.1016/s0065-2601(08)00404-8

Bhalla, M. i Proffitt, D. R. (1999). Visual-motor recalibration in geographical slant perception. Journal of Experimental Psychology: Human Perception and Performance, 25(4), 1076-1096.

Bruner, J. S. (1957). On perceptual readiness. Psychological Review, 64, 123-152.

Bruner, J. S. i Goodman, C. C. (1947). Value and need as organizing factors in perception. Journal of Abnormal and Social Psychology, 42, 33-44.

Bulier, J. (2001). Feedback connections and conscious vision. Trends in Cognitive Sciences, $5,369-370$.

Callaway, E. M. (2004). Feedforward, feedback and inhibitory connections in primate visual cortex. Neural Networks, 17, 625-632.

Callaway, E. M. (2005). Structure and function of parallel pathways in the primate early visual system. Journal of Physiology, 566, 13-19. doi:10.1113/jphysiol.2005.088047

Churchland, P. M. (1988). Matter and consciousness. Cambridge, MA: MIT Press. 
Clark, A. (2013). Whatever next? Predictive brains, situated agents, and the future of cognitive science. Behavioral and Brain Sciences, 36(3), 1-73. doi:10.1017/ S0140525X12000477

Cole, S., Balcetis, E. i Dunning, D. (2013). Affective signals of threat increase perceived proximity. Psychological Science, 24(1), 34-40. doi:10.1177/0956797612446953

Coren, S., Ward, L. M. i Enns, J. T. (2003). Sensation and perception (6th ed.). New York: Wiley.

Crick, F. i Koch, C. (1998). Constraints on cortical and thalamic projections: The no-strongloops hypothesis. Nature, 391(6664), 245-250. doi:10.1038/34584

Durgin, F. H. (2017). Counterpoint: Distinguishing between perception and judgment of spatial layout. Perspectives on Psychological Science, 12(2), 344-346. doi:10.1177/ 1745691616677829

Durgin, F. H., Baird, J., Greenburg, M., Russell, R., Shaughnessy, K. i Waymouth, S. (2009). Who is being deceived? The experimental demands of wearing a backpack. Psychonomic Bulletin \& Review, 16(5), 964-969. doi:10.3758/PBR.16.5.964

Durgin, F. H., Klein, B., Spiegel, A., Strawser, C. J. i Williams, M. (2012). The social psychology of perception experiments: Hills, backpacks, glucose and the problem of generalizability. Journal of Experimental Psychology: Human Perception and Performance, 38(6), 1582-1595. doi:10.1037/a0027805

Farah, M. J. (1990). Visual agnosia: Disorders of object recognition and what they tell us about normal vision. Cambridge, MA: MIT Press.

Feldman, F. i Friston, K. (2010). Attention, uncertainty, and free-energy. Frontiers in Human Neuroscience, 4(215), 1-23. doi:doi:10.3389/fnhum.2010.00215

Firestone, C. (2013). On the origin and status of the "El Greco fallacy". Perception, 42(6), 672-674. doi:10.1068/p7488

Firestone, C. i Scholl, B. J. (2014). "Top-down" effects where none should be found: The El Greco fallacy in perception research. Psychological Science, 25(1), 38-46. doi:10.1177/ 0956797613485092

Firestone, C. i Scholl, B. J. (2015a). Can you experience "top-down" effects on perception? The case of race categories and perceived lightness. Psychonomic Bulletin and Review, 22(3), 694-700. doi:10.3758/s13423-014-0711-5

Firestone, C. i Scholl, B. J. (2015b). Enhanced visual awareness for morality and pajamas? Perception vs. memory in "top-down" effects. Cognition, 136, 409-416. doi:10.1016/ j.cognition.2014.10.014

Firestone, C. i Scholl, B. J. (2016). Cognition does not affect perception: Evaluating the evidence for "top-down" effects. Behavioral and Brain Sciences, 39. doi:10.1017/ S0140525X15000965

Firestone, C. i Scholl, B. J. (2017). Seeing and thinking in studies of embodied "perception". Perspectives on Psychological Science, 12(2), 341-343. doi:10.1177/ 1745691616679944 
Fodor, J. A. (1983). Modularity of mind: An essay on faculty psychology. Cambridge, MA: MIT Press.

Friston, K. (2008). Hierarchical models in the brain. PLoS Computational Biology, 4(11), e1000211. doi:org/10.1371/journal.pcbi.1000211

Friston, K. (2010). The free-energy principle: A unified brain theory? Nature Reviews Neuroscience, 11(2), 127-138. doi:10.1038/nrn2787

Gantman, A. P. i Van Bavel, J. J. (2014). The moral pop-out effect: Enhanced perceptual awareness of morally relevant stimuli. Cognition, 132(1), 22-29. doi:10.1016/j. cognition.2014.02.007

Gilbert, C. D. i Li, W. (2013). Top-down influences on visual processing. Nature Reviews Neuroscience, 14(5), 350-363. doi:10.1038/nrn3476

Gilchrist, A., Kossyfidis, C., Bonato, F., Agostini, T., Cataliotti, J., Li, X., ... Economou, E. (1999). An anchoring theory of lightness perception. Psychological Review, 106(4), 795-834.

Golby, A. J., Gabrieli, J. D., Chiao, J. Y. i Eberhardt, J. L. (2001). Differential responses in the fusiform region to same-race and other-race faces. Nature Neuroscience, 4(8), 845850. doi:10.1038/90565

Goldstone, R. L. (1995). Effects of categorization on color perception. Psychological Science, 6, 298-394.

Goodale, M. A. i Milner, A. D. (1992). Separate visual pathways for perception and action. Trends in Neuroscience, 15(1), 20-25.

Gregory, R. L. (1970). The intelligent eye. London: Weidenfeld and Nicolson.

Grossberg, S. (1999). The link between brain learning, attention, and consciousness. Consciousness and Cognition, 8, 1-44.

Grossberg, S. (2013). Adaptive Resonance Theory: How a brain learns to consciously attend, learn, and recognize a changing world. Neural Networks, 37, 1-47.

Grossberg, S. (2017). Towards solving the hard problem of consciousness: The varieties of brain resonances and the conscious experiences that they support. Neural Networks, 87, 38-95. doi:org/10.1016/j.neunet.2016.11.003

Helmholtz, H. V. (1867/1924). Treatise on physiological optics (J. P. C. Southall, Trans. Vol. III). New York: Dover Press.

Hohwy, J. (2013). The predictive mind. Oxford: Oxford University Press.

Horr, N. K., Braun, C. i Volz, K. G. (2014). Feeling before knowing why: The role of the orbitofrontal cortex in intuitive judgments - an MEG study. Cognitive, Affective, \& Behavioral Neuroscience, 14(4), 1271-1285. doi:10.3758/s13415-014-0286-7

Huang, Y. i Rao, R. P. (2011). Predictive coding. Wiley Interdisciplinary Reviews: Cognitive Science, 2(5), 580-593. doi:10.1002/wcs.142 
Julesz, B. i Bergen, J. R. (1983). Human factors and behavioral science: Textons, the fundamental elements in preattentive vision and perception of textures. Bell System Technical Journal, 62(6), 1619-1645. doi:10.1002/j.1538-7305.1983.tb03502.x

Klein, O., Doyen, S., Leys, C., Magalhaes de Saldanha da Gama, P. A., Miller, S., Questienne, L. i Cleeremans, A. (2012). Low hopes, high expectations: Expectancy effects and the replicability of behavioral experiments. Perspectives on Psychological Science, 7(6), 572-584. doi:10.1177/1745691612463704

Kok, P., Brouwer, G. J., van Gerven, M. A. i de Lange, F. P. (2013). Prior expectations bias sensory representations in visual cortex. Journal of Neuroscience, 33(41), 16275-16284. doi:10.1523/jneurosci.0742-13.2013

Kveraga, K., Boshyan, J., Adams, R. B., Jr., Mote, J., Betz, N., Ward, N., .. Barrett, L. F. (2015). If it bleeds, it leads: Separating threat from mere negativity. Social Cognitive and Affective Neuroscience, 10(1), 28-35. doi:10.1093/scan/nsu007

Kveraga, K., Boshyan, J. i Bar, M. (2007). Magnocellular projections as the trigger of topdown facilitation in recognition. Journal of Neuroscience, 27(48), 13232-13240. doi:10.1523/JNEUROSCI.3481-07.2007

Lamme, V. A. F. (2003). Why visual attention and awareness are different. Trends in Cognitive Sciences, 7(1), 12-18.

Lamme, V. A. F. i Roelfsema, P. R. (2000). The distinct modes of vision offered by feedforward and recurrent processing. Trends in Neuroscience, 23(11), 571-579.

Lennie, P. (1998). Single units and visual cortical organization. Perception, 27, 889-935.

Levin, D. T. i Banaji, M. R. (2006). Distortions in the perceived lightness of faces: The role of race categories. Journal of Experimental Psychology: General, 135(4), 501-512. doi:10.1037/0096-3445.135.4.501

Long, G. M. i Toppino, T. C. (2004). Enduring interest in perceptual ambiguity: Alternating views of reversible figures. Psychological Bulletin, 130(5), 748-768. doi:10.1037/00332909.130.5.748

Lupyan, G. (2015). Cognitive penetrability of perception in the age of prediction: Predictive systems are penetrable systems. Review of Philosophy and Psychology, 6(4), 547-569. doi:10.1007/s13164-015-0253-4

Lupyan, G. (2017a). Changing what you see by changing what you know: The role of attention. Frontiers in Psychology, 8, 553. doi:10.3389/fpsyg.2017.00553

Lupyan, G. (2017b). How reliable is perception? Philosophical Topics, 45(1), 81-106. doi:10.17605/OSF.IO/R7SJJ

Macknik, S. L. i Martinez-Conde, S. (2009). The role of feedback in visual attention and awareness. U: M. S. Gazzaniga (Ur.), The cognitive neuroscience (str. 1165-1179). Cambridge, MA: MIT Press.

Macpherson, F. (2017). The relationship between cognitive penetration and predictive coding. Consciousness and Cognition, 47, 6-16. doi:10.1016/j.concog.2016.04.001 
Marr, D. (1982). Vision. San Francisco: Freeman.

Marr, D. i Poggio, T. (1976). Cooperative computation of stereo disparity. Science, 194, $283-$ 287.

Martinez-Conde, S., Cudeiro, J., Grieve, K. L., Rodriguez, R., Rivadulla, C. i Acuna, C. (1999). Effects of feedback projections from area 18 layers $2 / 3$ to area 17 layers $2 / 3$ in the cat visual cortex. Journal of Neurophysiology, 82(5), 2667-2675.

Mumford, D. (1992). On the computational architecture of the neocortex. II. The role of cortico-cortical loops. Biological Cybernetics, 66, 241-251.

O'Callaghan, C., Kveraga, K., Shine, J. M., Adams, R. B., Jr. i Bar, M. (2017). Predictions penetrate perception: Converging insights from brain, behaviour and disorder. Consciousness and Cognition, 47, 63-74. doi:10.1016/j.concog.2016.05.003

Olofsson, J. K., Nordin, S., Sequeira, H. i Polich, J. (2008). Affective picture processing: An integrative review of ERP findings. Biological Psychology, 77(3), 247-265. doi:10.1016/j.biopsycho.2007.11.006

Palmer, S. E. (1999). Vision science: Photons to phenomenology. Cambridge, MA: MIT Press.

Pessoa, L. i Adolphs, R. (2010). Emotion processing and the amygdala: From a "low road" to "many roads" of evaluating biological significance. Nature Reviews Neuroscience, 11(11), 773-783. doi:org/10.1038/nrn2920

Peterson, M. A. (1994). Object recognition processes can and do operate before figure-ground organization. Current Directions in Psychological Science, 3, 105-111.

Peterson, M. A. i Gibson, B. S. (1994). Object recognition contributions to figure-ground organization: Operations on outlines and subjective contours. Perception \& Psychophysics, 56(5), 551-564.

Peterson, M. A., Harvey, E. M. i Weidenbacher, H. J. (1991). Shape recognition contributions to figure-ground reversal: Which route counts? Journal of Experimental Psychology: Human Perception and Performance, 17, 1075-1089.

Pylyshyn, Z. (1999). Is vision continuous with cognition? The case for cognitive impenetrability of visual perception. Behavioral and Brain Sciences, 22, 341-365.

Raftopoulos, A. (2001). Is perception informationally encapsulated? The issue of the theoryladenness of perception. Cognitive Science, 25, 423-451.

Raftopoulos, A. (2009). Cognition and perception: How do psychology and neural science inform philosophy? Cambridge, MA: MIT Press.

Raftopoulos, A. (2014). The cognitive impenetrability of the content of early vision is a necessary and sufficient condition for purely nonconceptual content. Philosophical Psychology, 27(5), 601-620.

Rao, R. P. i Ballard, D. H. (1999). Predictive coding in the visual cortex: A functional interpretation of some extra-classical receptive-field effects. Nature Neuroscience, 2(1), 79-87. doi:10.1038/4580 
Ratner, K. G. i Amodio, D. M. (2013). Seeing "us vs. them": Minimal group effects on the neural encoding of faces. Journal of Experimental Social Psychology, 49, 298-301.

Riener, C. R., Stefanucci, J. K., Proffitt, D. R. i Clore, G. (2011). An effect of mood on the perception of geographical slant. Cognition and Emotion, 25(1), 174-182. doi:10.1080/02699931003738026

Rock, I. (1983). The logic of perception. Cambridge, MA: MIT Press.

Roelfsema, P. R. (2005). Elemental operations in vision. Trends in Cognitive Sciences, 9(5), 226-233. doi:10.1016/j.tics.2005.03.012

Schnall, S. (2017). Social and contextual constraints on embodied perception. Perspectives on Psychological Science, 12(2), 325-340. doi:10.1177/1745691616660199

Schnall, S., Zadra, J. R. i Proffitt, D. R. (2010). Direct evidence for the economy of action: Glucose and the perception of geographical slant. Perception, 39(4), 464-482.

Schubotz, R. I. (2015). Prediction and expectation. U: A. W. Toga (Ur.), Brain mapping: An encyclopedic reference (Vol. 3, str. 295-302). London: Academic Press.

Shaughnessy, J. J., Zechmeister, E. B. i Zechmeister, J. S. (2012). Research methods in psychology (9th ed.). New York: McGraw Hill.

Sherman, S. M. i Guillery, R. W. (2002). The role of the thalamus in the flow of information to the cortex. Philosophical Transactions of the Royal Society of London. Series B: Biological Sciences, 357(1428), 1695-1708. doi:10.1098/rstb.2002.1161

Shine, J. M., O'Callaghan, C., Halliday, G. M. i Lewis, S. J. (2014). Tricks of the mind: Visual hallucinations as disorders of attention. Progress in Neurobiology, 116, 58-65. doi:10.1016/j.pneurobio.2014.01.004

Song, H., Vonasch, A. J., Meier, B. P. i Bargh, J. A. (2012). Brighten up: Smiles facilitate perceptual judgement of facial lightness. Journal of Experimental Social Psychology, 48, 450-452. doi:10.1016/j.jesp.2011.10.003

Summerfield, J. J., Lepsien, J., Gitelman, D. R., Mesulam, M. M. i Nobre, A. C. (2006). Orienting attention based on long-term memory experience. Neuron, 49(6), 905-916. doi:10.1016/j.neuron.2006.01.021

Treisman, A. M. i Gelade, G. (1980). A feature-integration theory of attention. Cognitive Psychology, 12(1), 97-136. doi:org/10.1016/0010-0285(80)90005-5

Ungerleider, L. G. i Mishkin, M. (1982). Two cortical visual systems. U: D. J. Ingle, M. A. Goodale i R. W. J. Mansfield (Ur.), Analysis of visual behavior (str. 549-586). Cambridge, MA: MIT Press.

Van Bavel, J. J., Packer, D. J. i Cunningham, W. A. (2008). The neural substrates of in-group bias: A functional magnetic resonance imaging investigation. Psychological Science, 19(11), 1131-1139. doi:10.1111/j.1467-9280.2008.02214.x

Vandenbroucke, A. R. E., Fahrenfort, J. J., Meuwese, J. D. I., Scholte, H. S. i Lamme, V. A. F. (2016). Prior knowledge about objects determines neural color representation in human visual cortex. Cerebral Cortex, 26(4), 1401-1408. doi:10.1093/cercor/bhu224 
Vecera, S. P. i Farah, M. J. (1997). Is image segmentation a bottom-up or an interactive process? Perception \& Psychophysics, 59, 1280-1296.

Vetter, P. i Newen, A. (2014). Varieties of cognitive penetration in visual perception. Consciousness and Cognition, 27, 62-75. doi:org/10.1016/j.concog.2014.04.007

Waters, F., Collerton, D., Ffytche, D. H., Jardri, R., Pins, D., Dudley, R., ... Larøi, F. (2014). Visual hallucinations in the psychosis spectrum and comparative information from neurodegenerative disorders and eye disease. Schizophrenia Bulletin, 40, S233-S245. doi:10.1093/schbul/sbu036

Witt, J. K., Proffitt, D. R. i Epstein, W. (2004). Perceiving distance: A role of effort and intent. Perception, 33(5), 577-590. doi:10.1068/p5090

Woods, A. J., Philbeck, J. W. i Danoff, J. V. (2009). The various perceptions of distance: an alternative view of how effort affects distance judgments. Journal of Experimental Psychology: Human Perception and Performance, 35(4), 1104-1117. doi:10.1037/ a0013622

\title{
Can Cognition and Emotions Affect Vision?
}

\begin{abstract}
The paper reviews theoretical arguments and empirical findings in support and against the idea that cognitive processes (thinking, reasoning, expectations, and beliefs) or emotions and motivation can directly influence and change the content of vision. According to the modularity of mind hypothesis and Marr's computational theory, vision is an informationally encapsulated module with fixed, innate architecture. This innate architecture is based on a specific set of principles which are much different from general cognitive functioning. Vision must be cognitively impenetrable because its task is to create an exact mental representation of the external environment that will enable individual to navigate through it successfully. In contrast, according to predictive coding model as an example of the modern advocate of penetrability of vision, brain constantly generates predictions which facilitate and redirect visual information processing and, consequently, alters what we see. Recently, many behavioural and brain studies revealed that vision is indeed altered under the influence of learned associations and context as well as social cognition, motivation and emotions, thus lending support to the claim that vision is cognitively penetrable. However, numerous methodological and interpretational pitfalls have been identified in aforementioned research, resulting in the opposite conclusion. At the end, we described potential avenues for further theoretical and empirical research which will bring us closer to the answer to this perplexing question.
\end{abstract}

Keywords: experimental methodology, emotions, cognition, cognitive neuroscience, visual perception 


\title{
¿Pueden la cognición y las emociones influir en la vista?
}

\begin{abstract}
Resumen
En este trabajo se han mostrado argumentos teóricos y pruebas empíricas para los pros y los contras de la idea de que procesos cognitivos (pensamiento, razonamiento, expectativas y creencias) o emociones y motivación pueden influir directamente en la vista y cambiar su contenido. Según la hipótesis sobre la modularidad de la mente y la teoría computacional de Marr, la vista es un módulo cerrado de informaciones con la arquitectura fija, innata. Se basa en los principios específicos que son significativamente diferentes del funcionamiento cognitivo general. La vista tiene que ser cognitivamente impenetrable porque tiene que crear una representación mental exacta del mundo exterior y así posibilitar a un individuo buen funcionamiento en el mismo. Por lo contrario, según el modelo de codificación predictiva, como un modelo contemporáneo de abogar por la penetrabilidad de vista, el cerebro genera continuamente las predicciones que facilitan y dirigen el procesamiento de informaciones sensoriales y en consecuencia cambian lo que vemos. Últimamente, muchas investigaciones conductuales y neurocientíficas muestran que la vista de verdad cambia bajo la influencia de asociaciones aprendidas y el contexto, tanto como bajo la influencia de cognición social, motivación y emociones, lo que lleva a conclusión de que la vista es cognitivamente penetrable. Sin embargo, en dichas investigaciones se han identificado numerosas dificultades metodológicas e interpretativas de las que surge una conclusión contraria. Al final, se han descrito posibles direcciones para futuras investigaciones teóricas y empíricas que deberían acercarnos a la solución de esta cuestión compleja.
\end{abstract}

Palabras clave: metodología experimental, emociones, cognición, neurociencia cognitiva, vista

Primljeno: 18.09.2017. 